\title{
NGOs and the environment
}

\author{
Naghmeh Nasiritousi
}

\section{Introduction}

Non-governmental organizations (NGOs) have long been recognized as crucial actors in global environmental politics. With their involvement in issues such as biodiversity and conservation, desertification, transboundary air pollution, and climate change, NGOs have become significant actors on the global stage (Betsill and Corell 2007; Finger and Princen 1994). The burgeoning literature on NGOs has highlighted their different roles in global environmental politics. For instance, they have been described as "agitators for environmental action, architects of governance solutions, and entrepreneurs for new sorts of initiatives" (O’Neill 2014: 26). Similarly, Betsill (2015: 251) describes NGOs involved in climate change governance as "activists raising awareness and calling for action; as diplomats working with governments to craft climate policies; and as governors developing new mechanisms for steering society towards a low-carbon future". More generally, Nasiritousi (2016: 2) describes their roles as "shapers of information and ideas, brokers of knowledge, norms and initiatives, and doers of implementing policies and influencing behaviours".

What all these accounts of NGO activities in the environmental field have in common is that NGOs are political actors with important roles to play in the governance of environmental issues (see also Burgiel and Wood 2012). What is sometimes not adequately highlighted, however, is the diversity in the types of actors that make up the NGO community seeking to address environmental issues. With some of the literature on the roles of NGOs mainly focusing on describing influential NGOs that work for the public good, it is often easy to forget that NGOs come in many shapes and sizes. Nasiritousi (2016) criticizes the often rosy view of NGOs in the literature and points out that different types of NGOs fulfill various roles to different extents.

This chapter examines NGOs that play a role in addressing environmental issues. While NGOs work at many levels, from the local to the global, the focus in this chapter will be on those that work at the international level. The definition of NGOs used in this chapter will thus be broad and follow the approach adopted by the UN when admitting observer organizations (see section below on Major Groups). The aim of the chapter is to provide an overview of categories of NGOs in this field, and to outline the range of approaches adopted by such NGOs, the strategies used, and their influence. Hence, the chapter discusses the plurality of NGOs 
involved in global environmental governance and the main paths through which they seek to influence outcomes. While the chapter examines NGOs involved in the area of environment and sustainable development in general, its empirical focus will be on NGOs that work in the realm of climate change governance.

The remainder of the chapter proceeds as follows. The next section outlines milestones in international efforts to address sustainable development and negotiate multilateral environmental agreements, and provides an overview of NGO involvement at these events. Next, the different types of NGOs are discussed, highlighting the diversity of NGOs and in general terms describing the range of approaches adopted by such NGOs. Subsequently, a more detailed analysis of the roles of NGOs in global climate change governance will be provided, with a discussion of NGO strategies used and their influence. The final section concludes with a discussion about the implications of greater NGO activities for the legitimacy and effectiveness of global environmental governance and explores future research avenues.

\section{A history of global environmental governance and the roles of NGOs therein}

Environmental problems, such as biodiversity loss and air pollution, can have both local and global effects. While human activity has always impacted on the environment, technological advances since the Industrial Revolution and processes of globalization have contributed to multiplying and amplifying those effects. The twentieth century thus saw an acceleration in the scale and scope of environmental problems (O’Neill 2017). Given the transboundary nature of many environmental problems, international cooperation has been necessary to address them. Environmental problems such as climate change, acid rain, and stratospheric ozone depletion are transnational in nature, meaning that even powerful countries cannot take unilateral action to address such problems (O’Neill 2017). Consequently, international cooperation on environmental issues has taken many forms.

One important form of international cooperation is through the signing of multilateral environmental agreements (MEAs). In fact, researchers have coded over 1,280 MEAs that states have devised to tackle environmental problems (Mitchell 2018). NGOs have played a prominent role in many of these processes - from raising awareness of environmental issues and getting them on the international agenda, to influencing outcomes, implementing decisions, and monitoring state commitments (Raustiala 1997).

One of the first milestones in global environmental governance was the 1972 UN Conference on the Human Environment in Stockholm, Sweden. Attended by 113 countries and over 250 NGOs as observers, this conference laid the foundation for modern global environmental governance (Willetts 1996). This was also a key moment for NGOs for several reasons. First, NGOs had been enlisted as experts even in the preparatory phase of the conference, thus having the chance to influence documents that set the scene for the conference. Second, forty-seven countries included NGOs as part of their official delegation, thereby providing those NGOs with new insights into interstate negotiations. Third, the conference included a parallel open forum, the Environment Forum, where NGOs could more freely express their views and highlight causes. Such discussions proved to be important, as for example through this space the issue of whaling was pushed onto the diplomatic agenda of the official conference (Willetts 1996).

This model of state-NGO engagement at the international level has since been adopted at other multilateral environmental conferences, even though certain states have been suspicious of NGOs and have sought to curtail their activities in environmental negotiations (Willetts 1996). At the follow-up summit to the Stockholm conference that took place twenty years later - the 
Earth Summit in Rio de Janeiro, Brazil in 1992 - NGOs had mobilized to make sure that their voices were not left out of the summit: 2,400 NGO representatives attended the Earth Summit as observers (which gives them participation rights but no negotiation or decision-making rights) and 17,000 attended the parallel NGO Forum in what has been described as "a watershed moment in NGO engagement in international environmental policy discussions" (Burgiel and Wood 2012: 127). The sheer number of participating NGOs was in stark contrast to how international meetings were conducted in other policy areas, such as in international trade and security (O'Neill 2014). This event has been said to mark the beginning of "the participatory turn of global environmental governance" (Bäckstrand 2006: 470) whereby the participation of NGOs became seen as integral to the legitimacy of international environmental cooperation. NGO involvement became a cornerstone of the documents that the Earth Summit gave rise to, including the Rio Accords and Agenda 21 (Bäckstrand 2006).

NGO participation continued to grow in the two succeeding UN sustainable development conferences. At the 2002 World Summit on Sustainable Development in Johannesburg, South Africa, there were $8,000 \mathrm{NGO}$ representatives. While this summit did not produce any major treaties, agreement was reached on smaller-scale initiatives known as "Type II partnerships" where NGOs joined forces with governments and other actors to implement initiatives (O'Neill 2014). Similarly, the Rio+20 Conference in 2012 attracted thousands of NGO representatives. At this conference, NGOs were actively involved in trying to influence the outcome document “The Future We Want”, as well as organizing side-events and events outside the conference in what has been described as "an extraordinary trade fair of political, social, technological and commercial ideas" (Vidal 2012). NGOs were also involved in the more than 700 voluntary commitments for sustainable development that were registered in connection with the Rio+20 conference as a way to spur action on sustainable development (Ramstein 2012). NGOs continued to stay engaged in the processes that originated at Rio+20 and which in 2015 led to the adoption of the 2030 Agenda for Sustainable Development and its seventeen Sustainable Development Goals (Kanie and Biermann 2017). Through extensive consultations, the world now has seventeen universal goals and 169 specific targets for achieving sustainable development. As part of this agenda, NGOs have been recognized for playing an important role in implementing, monitoring, and reviewing actions toward sustainable development (UN 2015).

What this historical overview of NGO involvement in the key summits of global environmental governance shows is that NGOs have become an integral part of global environmental governance. Whereas at first only NGOs with particular expertise were invited in the run-up to the 1972 Stockholm conference (Willetts 1996), both the number and types of NGOs quickly grew for subsequent meetings. In fact, the recognition at the Earth Summit in 1992 that sustainable development can only be achieved through the engagement of a broad set of actors meant that a system was drawn up to organize interactions with different types of NGOs. NGOs thus came to be organized into "Major Groups", as a way to categorize organizations with broadly similar interests. The next section outlines the Major Groups and discusses other ways of differentiating those NGOs that are involved in addressing issues of the environment at the global level.

\section{Similarities and differences between NGOs in global environmental governance}

The Earth Summit's Agenda 21 recognizes the importance of NGOs to address sustainable development and categorizes them into nine Major Groups. These are: Women; Children and Youth; Indigenous Peoples; Local Authorities; Workers and Trade Unions; Business and Industry; Scientific and Technological Community; Farmers; as well as a general category called 
Non-Governmental Organizations. ${ }^{1}$ This list provides an indication of the breadth of interests represented by the NGO community attending UN environmental conferences. Within the different categories, there are also a heterogeneous set of organizations often with a conflicting set of priorities or interests. For example, there are secular organizations and religious organizations, organizations that prioritize economic development and those that prioritize nature conservation, those that support local solutions and those that support global solutions. What most of these NGOs have in common, though, is that they are advocacy organizations, working to further their particular cause (O’Neill 2014).

This thus means that even within a constituency such as environmental NGOs, that to the outside might appear relatively homogenous in their causes, there is great variation in the policies that they advocate. An example is on the topic of conservation, where there have been conflicts between some conservation NGOs and other environmental NGOs on the most preferred policies for protecting wildlife, and in particular on whether and how to work with local communities (Duffy 2013; Chapin 2004). More broadly, there have been significant disagreements between "light green" and more radical environmental NGOs on how to relate to current power structures and dominant discourses (Dauvergne and LeBaron 2014).

Except for their differing causes, the differences that set NGOs apart include resources, strategies, size, level of professionalization, membership base, and access to policy-makers. For example, large Northern NGOs have a different level of capacities compared to grassroots NGOs from the South (O'Neill 2014). Well-known NGOs such as the World Wide Fund for Nature (WWF) or Greenpeace have several decades' worth of experience of working on environmental issues and therefore have access to well-established networks with policy-makers and other key actors. They both have a considerable membership base and sizeable funds. These NGOs can therefore afford to send their representatives to several international environmental conferences each year. They tend to have chapters in different countries and can thus work on multiple issues at the same time. Smaller grassroots organizations, in contrast, do not have the same access to resources and therefore their presence at global conferences tends to be more limited - with participation going up when the conference is located in close proximity to where those groups are based, so that local groups can more easily travel to the conference (Nordang Uhre 2013).

Moreover, the range of approaches that different types of NGOs employ differ. Depending on how their agendas align, NGOs can choose a collaborative or confrontational approach when targeting other actors (Rietig 2016). NGOs that have local governments or businesses as their members more often rely on insider strategies compared to, for example, youth groups or environmental NGOs that also rely on outsider strategies such as protests and demonstrations. The former generally have a closer relationship with policy-makers and thus focus their activities on lobbying (Betzold 2013). In contrast, at Rio+20 youth groups, environmental NGOs and indigenous groups staged a demonstration when they felt that they had exhausted the insider strategies available to them (Watts 2012). While most NGOs seek to employ both insider and outsider strategies, some prefer not to participate at the official meetings but instead make their voice heard at alternative conferences, such as the People's Summit organized in conjunction with Rio+20. At the other end of the spectrum, some NGOs are invited to sit on the official government delegations, thereby gaining access to negotiations that are closed to observers. However, countries tend to enforce strict guidelines on what such NGOs can and cannot say; those NGOs thereby lose much of their independence while they sit on the delegation (Nasiritousi and Linnér 2016).

This difference in which NGOs participate at the official events of course plays a part in determining which NGOs can influence the official outcome documents. Influencing the text generally requires extensive cooperation with one or more state delegations (Betsill and Corell 2007). 
The chances for this go up if NGO representatives know the issues well, speak fluent English (the main negotiating language) and are versed in the technical language of the proceedings, and have a good working relationship with negotiators, all of which is associated with Northern professional NGOs. Smaller NGOs can, however, increase their impact by joining larger networks of NGOs (O’Neill 2014). Such an example is the Climate Action Network (CAN) which is a worldwide network of around 1,000 NGOs from over 100 countries working to address climate change. ${ }^{2}$ By joining forces, smaller NGOs can contribute to influencing policies through the wider network that share a common goal. Thus by working together and thereby representing more actors, networked organizations can wield greater influence than individual organizations (O’Neill 2014).

Participation in international environmental policy processes is, however, only one way in which NGOs seek to influence global environmental governance. Some target other international bodies, such as multilateral financial or trade institutions like the World Bank or the World Trade Organization, to seek to green the activities of such bodies (Gutner 2012). Another strategy is to work directly with large companies to green their business practices, such as the pioneering partnership between the Environmental Defense Fund and McDonald's in the 1990s that reduced the fast food company's packaging waste (MacDonald 2012). Another type of cooperation with companies is the setting up of certification schemes that seek to drive sustainability in sectors such as timber and fish. Well-known examples of this are the Forest Stewardship Council (FSC) and the Marine Stewardship Council (MSC). In these cases NGOs (such as WWF which has been a key actor in both schemes) have deemed that interstate cooperation has not produced adequate governance instruments for protecting valuable resources and thus have set up their own initiatives to promote sustainable practices. This type of activity is a more direct, but costly, way of influencing global environmental governance as it requires sustained multi-stakeholder cooperation. Its effectiveness is also not a given as it builds on voluntary participation, and being a market-driven form of environmental governance it is susceptible to being accused of greenwashing (see e.g. FSC-Watch 2011).

These latter examples show how NGOs may also engage in what Wapner (1995) calls "politics beyond the state", whereby they target actors other than state actors. Notably, by raising awareness and changing practices, NGOs have been successful in highlighting sustainability issues to the broader public. Groups such as Zero Waste Europe have, for example, contributed to raising awareness of the concept of the circular economy and the damaging effects of plastics on the environment. ${ }^{3}$ By changing attitudes about acceptable practices, NGOs can support shifts in the environmental impacts of consumption and production patterns. The tactics for doing so, however, differ. In particular, conflicts have emerged between different environmental NGOs in how they approach the corporate sector, specifically on whether they choose collaboration or confrontation. WWF has, for example, been criticized on the grounds that they work too closely with corporations and that they thereby shy away from calling out unsustainable practices (Dauvergne and LeBaron 2014).

In sum, there is a considerable breadth of NGOs that work on issues of the environment and they do so at multiple sites and in many different ways. Having outlined the general contours of NGO involvement in global environmental governance, the next sections turn to a more indepth examination of their different roles in global climate change governance.

\section{NGOs in global climate change governance ${ }^{4}$}

Governing climate change represents a defining challenge for the twenty-first century. Climate change has been depicted by scholars as a wicked problem, meaning that the problem resists 
resolution because of its complex nature and lack of simple solutions (Levin et al. 2012; Hoffmann 2011). Because the issue of climate change includes discussions about other political domains, such as energy, finance, food security, and health, it has attracted the involvement of a myriad of actors that "are operating across various scales, in different regions, and are seeking to mobilise a wide range of discourses, tools, techniques and practices in order to govern" (Bulkeley et al. 2014: 38). The defining features of global climate change governance are thus that it includes a range of actors, requires cooperation across multiple levels, and is transnational in scope. The governing of climate change therefore represents a microcosm of wider global environmental governance (Green 2013). Moreover, relevant for the purposes of this chapter, NGOs have had important roles to play in climate change governance from the start.

While the history of climate change science dates back to the 1800 s, it was not until the latter parts of the twentieth century that this problem reached the international political agenda. Environmental as well as research-oriented NGOs, such as the Beijer Institute, the Environmental Defense Fund, the World Resources Institute, and the Woods Hole Research Center, were instrumental in placing climate change onto the international policy agenda (Betsill 2015). Through the organization of conferences where policy action to address the emerging consensus on climate change was called for, such NGOs managed at the end of the 1980s to prompt the international community to come up with a policy process to address climate change. In 1988, the World Meteorological Organization and the UN Environment Program set up the Intergovernmental Panel on Climate Change (IPCC) in order to provide policy-makers with an assessment of the science on climate change. ${ }^{5}$ The IPCC allows for NGOs "qualified in matters covered by the IPCC" to participate in its sessions. ${ }^{6}$ Currently there are eighty-seven NGOs accredited, among which include such disparate organizations as the Third World Network, Wetlands International, and the World Coal Institute.?

Having succeeded in raising awareness of the climate change problem, NGOs also got involved in the policy process to address the issue. At the Earth Summit in 1992, the United Nations Framework Convention on Climate Change (UNFCCC) was opened up for signatures. Being tasked to formulate an international policy response to address climate change, the UNFCCC has turned into a key venue where the multilateral (state-centric) and the transnational (including NGO) arenas meet (Bäckstrand et al. 2017; Lövbrand et al. 2017; Betsill 2015). The UNFCCC conferences are thus important for global climate change governance both in terms of the significance of the decisions negotiated and in terms of serving as a platform for the exchange of views and ideas amongst a range of stakeholders. The conferences offer NGOs, who are accredited with observer status, the opportunity to lobby negotiators to influence climate change policy (Hanegraaff 2015; Betzold 2014). They also provide a platform for NGOs to showcase their own initiatives in the field of climate change at exhibits and side-events and to network with other stakeholders (Schroeder and Lovell 2011; Hjerpe and Linnér 2010). The UN climate change conferences have thus been described as "messy political sites, where a multitude of actors come together to exchange ideas and knowledge, benchmark climate performance, build interpersonal relationships, organize resistance and propose policy alternatives in parallel to, and in view of, the interstate negotiations" (Lövbrand et al. 2017: 581).

Indeed, this international environmental regime is considered to be one of the most open to NGO involvement in terms of allowing a multitude of NGOs to attend its conferences and having relatively generous rules for NGOs on access to documentation, making statements, submission of written input, and consultations with the presiding officers and the Executive Secretary. The Secretariat also has an NGO-liaison section, which can be viewed as a sign of the deep engagement with NGOs (Nasiritousi and Linnér 2016; Depledge 2005). At the first conferences, particularly environmental NGOs, business and industry NGOs, and research NGOs 
participated and sought to influence policy-makers. Over time, however, both the number and range of participating NGOs grew, with NGO representatives at times outnumbering state delegates (Lövbrand et al. 2017; Depledge 2005). In fact, interest from the NGO community to participate in UNFCCC conferences has grown so much that the UNFCCC introduced a quota system for observer access to the conferences after COP 15 in Copenhagen in 2009. Figure 23.1 shows the growth of admitted observer organizations throughout the over twenty years of international climate change negotiations under the auspices of the UNFCCC.

NGOs attending UNFCCC conferences are organized into nine constituencies with diverse but recognizable interests that mirror the Major Groups. These are: Business and industry NGOs (BINGOs), Environmental NGOs (ENGOs), Farmers (F), Indigenous peoples organizations (IPOs), Local government and municipal authorities (LGMAs), Research and independent NGOs (RINGOs), Trade union NGOs (TUNGOs), Women and Gender Constituency (WGC), and Youth NGOs (YOUNGOs) (Nasiritousi et al. 2016a). Figure 23.2 shows that ENGOs, RINGOs, and BINGOs still make up the majority of NGOs accredited to the UNFCCC. YOUNGOs have increased rapidly in recent years, albeit from a very low level. The non-affiliated category includes NGOs that do not wish to be part of a constituency or groups that do not fit within the established categories, such as faith groups.

Within the constituencies there is a wide range of actors with different interests. The business community, for example, ranges from groups that are opposed to international regulations to groups that see business opportunities in stricter climate policies (Betsill 2015). This example highlights conflicts in the NGO community over the policy response to climate change. Nasiritousi et al. (2014) found that views on the most effective solutions to address climate change diverge more between groups of NGOs than between NGOs and state actors. This could also be seen in the split of the environmental NGOs into a more radical faction in 2009 with the emergence of Climate Justice Now! and Climate Justice Action that emphasize the need for structural changes in the global economy and the need to bring justice to the victims of climate change (Betsill 2015; O’Neill 2014). Overall, recent years have seen a growth in the plurality of

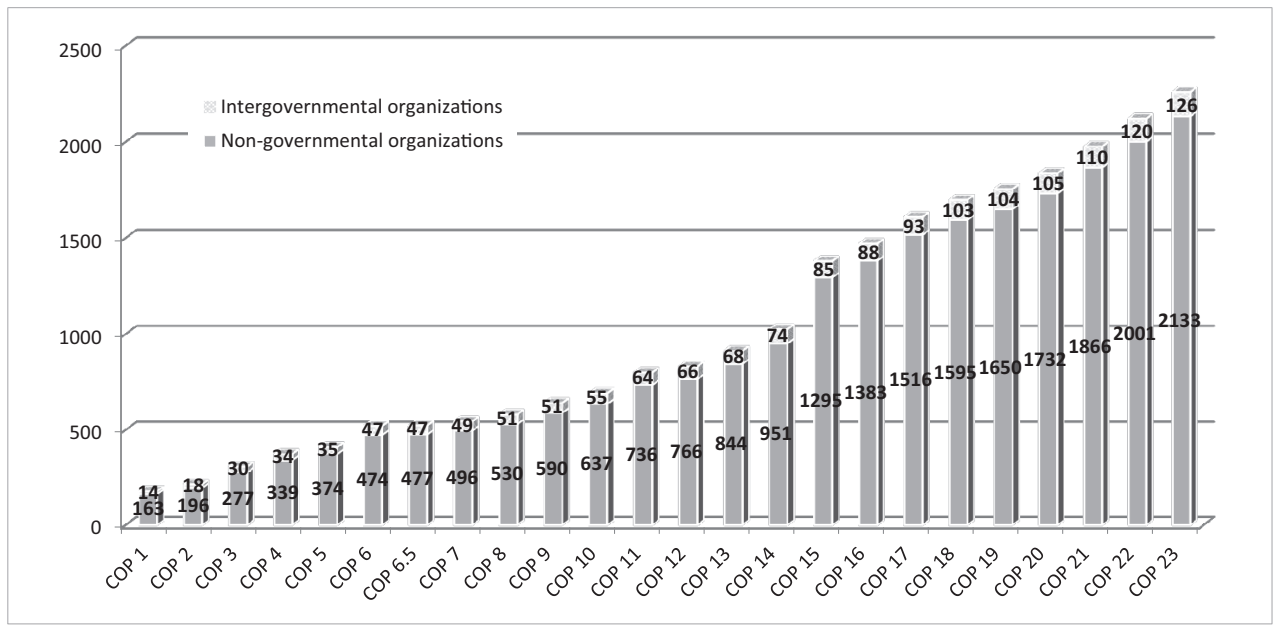

\section{Figure 23.1 Cumulative admission of observer organizations}

This figure shows the cumulative admission of observer organizations - intergovernmental organizations (IGOs) and non-governmental organizations (NGOs) - from UNFCCC conference of parties (COP) 1 in 1994 to COP 23 in 2017. Source: UNFCCC. 


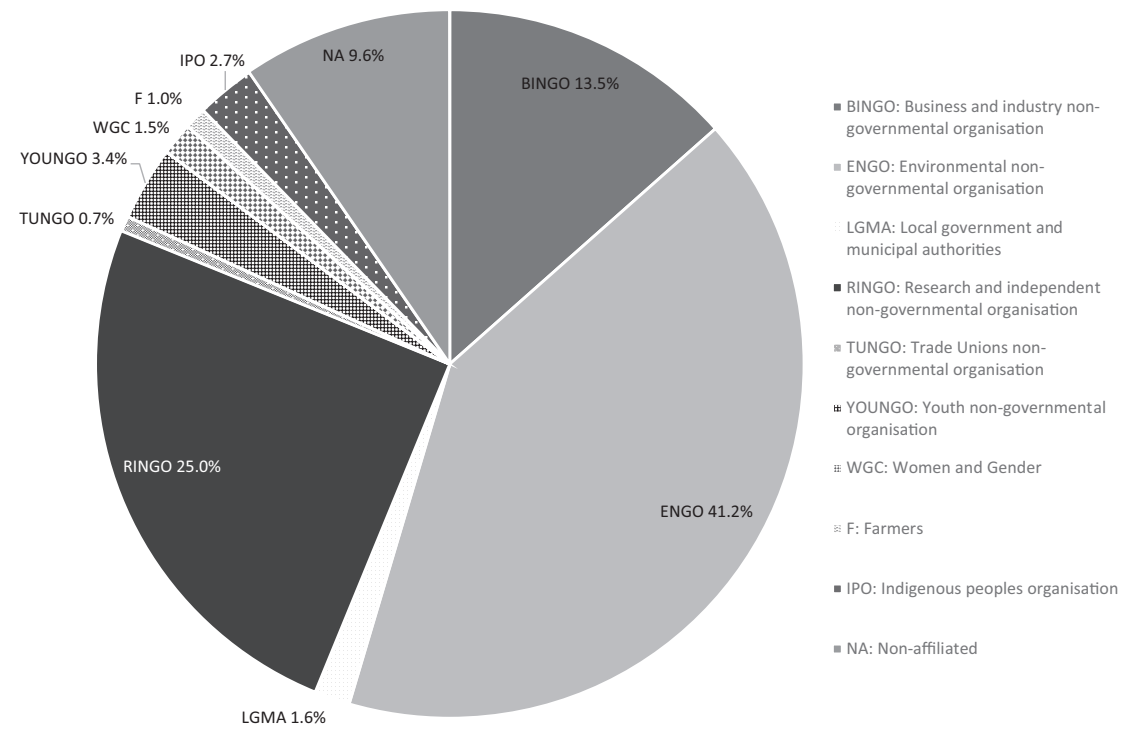

Figure 23.2 Constituency affiliation of admitted NGOs (as at December 2017)

This figure shows the constituency affiliation of admitted NGOs to the UNFCCC as at December 2017. The constituency groups are: Business and industry NGOs (BINGOs), Environmental NGOs (ENGOs), Farmers (F), Indigenous peoples organizations (IPOs), Local government and municipal authorities (LGMAs), Research and independent NGOs (RINGOs), Trade union NGOs (TUNGOs), Women and Gender Constituency (WGC), and Youth NGOs (YOUNGOs). NA in the figure refers to non-affiliated. Source: UNFCCC.

NGOs attending the UNFCCC conferences, with those focusing on, for instance, human rights, social justice, peacebuilding, and poverty increasingly participating (Hadden 2015).

In sum, the constituencies vary in size, resources, and approach to climate diplomacy. They encompass a wide range of actors with varying interests and views, and different capabilities to promote these interests with authority. To understand the roles of these actors in global climate change governance, it is thus important to examine the range of approaches adopted by NGOs, the strategies used, and their influence in international climate diplomacy. This would only reveal part of the story, however, as many more NGOs are engaged in global climate change governance outside the UN process (Nasiritousi et al. 2016b; Betsill 2015). The remainder of the chapter therefore examines how NGOs are involved in global climate change governance both as observers at the UNFCCC and beyond the international climate change negotiations.

\section{NGOs in climate diplomacy and beyond}

The literature has identified three broad paths through which NGOs can influence policy outcomes despite lacking legislative powers. First, NGOs can play a role in shaping policy outcomes by carrying out tasks mandated to them by states or by partnering with states to carry out governance activities. Second, NGOs can try to influence state policy through lobbying or advocacy. Third, NGOs can be entrepreneurial through independent action on the ground, for example by forming transnational governance initiatives with other non-state actors (Nasiritousi 
2016; Bulkeley et al. 2014; Green 2013). The area of climate change governance offers many examples of NGOs trying to pursue these paths.

For example, forty-six NGOs have partnered with states and intergovernmental organizations to join the Climate and Clean Air Coalition (CCAC) with the aim to reduce short-lived climate pollutants. Such NGOs include the Bellona Foundation and the C40 Cities Climate Leadership Group. ${ }^{8}$ Another example of NGO involvement in a state-led climate change initiative is the NDC Partnership, which is a coalition of countries and international organizations that seek to drive ambitious climate action by mobilizing support for effective implementation of climate goals. This Partnership is hosted by the World Resources Institute and has ICLEI Local Governments for Sustainability as an associate member. ${ }^{9}$ By partnering with states and intergovernmental organizations, NGOs obtain the opportunity to develop voluntary initiatives and contribute to implementing policies. This type of engagement, however, usually requires particular competencies or resources and is therefore not a path that is open to all types of NGOs.

Examples of the second type of path through which NGOs can influence policy outcomes are numerous. Both at the international climate change negotiations and beyond, many NGOs seek to lobby policy-makers and influence other actors through advocacy. Lobbying and advocacy take place at many levels (i.e. local, regional, international) and involve a range of strategies. According to Keck and Sikkink (1998), strategies range from information politics (i.e. generation and dissemination of relevant information), symbolic politics (i.e. the use of symbols and narratives to connect with various audiences), and leverage politics (i.e. putting pressure on or allying with stronger actors), to accountability politics (i.e. monitoring actions and holding actors to promises made, for example through naming and shaming tactics).

An example of NGOs employing all of these tactics is the coalition of NGOs that advocate for the need to hold much of the remaining reserves of fossil fuels in the ground to prevent catastrophic climate change. Through the Big Shift Global campaign, NGOs such as Oil Change International, Friends of the Earth, 350.org, and Christian Aid have disseminated information to policy-makers and the media on why fossil fuel subsidies need to be phased out as soon as possible. ${ }^{10}$ Their campaign has been boosted by the news from the World Bank Group at the One Planet Summit in 2017 that they will take a number of steps to strengthen climate action and drive decarbonization, including ending finance toward upstream oil and gas by $2019 .{ }^{11}$ Moreover, Carbon Action Tracker has popularized the term carbon bubble, which refers to the investment bubble that would burst if the world accepts that much of the world's fossil fuel reserves must be kept in the ground in order to adequately address climate change (Nasiritousi 2017; Ayling and Gunningham 2017). This has contributed to putting a focus on carbon risk amongst policy-makers and financial institutions (see e.g. Bowen and Dietz 2016). Furthermore, through a global divestment campaign, NGOs such as 350.org have been instrumental in challenging the fossil fuel sector both politically and financially by organizing protests and campaigns that have led to 831 institutions fully or partially divesting from fossil fuels to an approximate value of $\$ 6$ trillion. ${ }^{12}$ Finally, sprung out of opposition toward plans by the Norwegian government to expand oil exploration in the Lofoten area, NGOs have taken the Norwegian government to court for breaching their climate change obligations and rallied over 220 actors from fifty-five countries around the Lofoten Declaration, calling for a managed decline of the fossil fuel sector. ${ }^{13}$ Although losing the court case, the NGOs struck a partial victory when Norway's government recently announced that oil exploration at Lofoten will be banned until at least 2021. ${ }^{14}$ These examples show that by working on many fronts and together with different actors, NGOs can have an influence in framing discussions and decisions and thereby contribute to addressing climate change.

It is worth keeping in mind, however, that since NGOs' views often diverge, they can "lobby for either side of a cause" (O’Neill 2014: 41). A notable example of an NGO that 


\section{Naghmeh Nasiritousi}

worked to undermine climate change action was the Global Climate Coalition (GCC), a wellfunded American-based NGO supported by many large corporations, including several major oil and gas companies. This NGO (active 1989-2001) lobbied both at the domestic and international levels to prevent strong climate change policies and launched a campaign that branded the Kyoto Protocol as unfair to American businesses. Such actions influenced the US Congress and eventually led to the US withdrawing from Kyoto, thereby weakening international cooperation on climate change (Downie 2014). According to Betsill (2015: 256), "working simultaneously at the international and national levels allows NGOs to invoke the 'boomerang strategy' and put pressure on states from above and below". More generally, studies have found that influence by NGOs at multilateral climate change negotiations requires consistent engagement by NGOs and that NGOs tend to be more successful in raising issues and shaping the agenda than having their positions reflected in the official agreements (Betsill 2015; Downie 2014).

The third path through which NGOs can influence outcomes is by taking entrepreneurial action by establishing their own forms of climate initiatives together with other transnational actors. This type of activity thus does not rely on working with or influencing states, but has instead been described as "agency beyond the state" (Betsill 2015: 257). An example of such an NGO initiative is the Science-Based Targets Initiative, which is a collaboration between CDP, World Resources Institute, WWF, and the UN Global Compact and works with companies to set science-based targets for emission reductions. ${ }^{15}$ Another notable example is the GHG Protocol, which is the world's most widely used standard for greenhouse gas accounting and was developed by the World Resources Institute and the World Business Council on Sustainable Development. ${ }^{16}$ Focusing on cities, ICLEI's GreenClimateCities program offers local governments a framework for pursuing urban low-carbon development. ${ }^{17}$ These cases highlight how NGOs can fill gaps in global climate change governance to address issues that states have failed to address or have not adequately responded to.

The realization that NGOs fulfill multiple roles has prompted the UNFCCC to seek to engage NGOs beyond being mere observers at the conferences. The UNFCCC's Global Climate Action framework launched in 2016 together with the Non-State Actor Zone for Climate Action (NAZCA) and the International Cooperative Initiatives (ICI) portals aim to catalyze and support climate action beyond states. ${ }^{18}$ Such orchestration efforts have, however, been criticized on both effectiveness and legitimacy grounds (Chan et al. 2018; Bäckstrand and Kuyper 2017). Some of the problems with these types of voluntary initiatives are that they are difficult to follow up on and lack accountability mechanisms. In addition, there is a skewed distribution of initiatives geographically which means that the people most vulnerable to climate change are less likely to directly benefit from such initiatives (Chan et al. 2018). More generally, Bulkeley et al. (2014) found many of the transnational initiatives to be in line with a dominant liberal environmentalist ideology with an emphasis on market governance. An over-reliance on voluntary initiatives thus risks leading to a marketization of governance and the strengthening of already strong interests (Bulkeley et al. 2014). The enhanced role of NGOs in the work of the UNFCCC has also brought new conflicts between different groups of NGOs to the fore. In particular, a coalition of NGOs is urging the UNFCCC to establish a conflict of interest policy to limit the influence of businesses such as fossil fuel companies whose business interests conflict with the aims of the UNFCCC (UNFCCC 2017). So far UNFCCC member countries have resisted introducing such a policy on the basis that the business constituency is important for the work of the UNFCCC.

The examples above show that NGOs have influenced global climate change governance in different ways. It also shows, however, imbalances in the strength of different NGOs, where particularly well-resourced NGOs are more successful in making a mark. Beyond the issue of resources, Nasiritousi et al. (2016b) showed how the different NGO constituencies have comparative 
advantages in different governance activities. Finding distinct governance profiles for each constituency, the study showed, for example, that influence and action seem to be most associated with BINGOs and somewhat with LGMAs, ideas and expertise with RINGOs, and awareness raising and representation with ENGOs and IPOs. These governance profiles correspond well with the governance profiles of the Major Groups that participated in the Rio+20 conference, indicating that they are not limited to the field of climate change (Linnér et al. 2013). An implication of this is that different types of NGOs may cooperate with other categories of NGOs in order to achieve greater impact across the policy cycle. The trend toward partnerships in global climate change governance may reflect this insight.

Taken together, NGOs can affect outcomes by contributing with ideas, raising awareness, shaping discussions, influencing decisions, implementing policies, and normalizing actions. For instance, some of the initiatives that started as non-state actor experimentation for climate action (Hoffmann 2011), such as the Carbon Disclosure Project (CDP), have now developed into international cooperative initiatives that are highlighted by the UNFCCC as important governance arrangements (Hjerpe and Nasiritousi 2015). Thus by writing reports, participating in awareness-raising activities, launching educational and media campaigns etc., NGOs may influence how issues are perceived and discussed. Through lobbying for particular solutions or through demonstrations or protests, NGOs can seek to put pressure on policy-makers and other actors to influence outcomes. Finally, by forging partnerships and launching their own governance initiatives, NGOs can seek to steer society toward a particular cause. In sum, this implies that authority is increasingly shared between states and non-state actors in global climate change governance and that NGOs engage in governance activities that are broader than merely seeking to influence the negotiating text of intergovernmental meetings.

\section{Conclusion}

This chapter has shown that NGOs are important actors in global environmental governance. NGOs contribute to global environmental governance in different ways and to different degrees by offering knowledge and expertise, moral arguments and new ideas, and by taking action on implementing policies and assuming the role of stakeholders. The approaches used by NGOs, and ultimately their influence, depend in some part on their resources and their comparative advantages in terms of, for example, expertise, access to policy-makers, or the ability to join networks. The overall landscape of NGOs involved in global environmental governance is hence characterized by plurality, inequality, and contradictions. NGOs pursue different causes to varying degrees of success which raises important questions about the implications of the growing participation by NGOs in global environmental governance for issues of legitimacy and effectiveness.

With the growing prominence of NGOs in global environmental governance, a key question that this chapter highlights is whether this development strengthens already strong actors or whether it provides opportunities for marginalized voices to be heard. The results from Nasiritousi et al.'s (2014) study indicate that mainstream voices dominate at the climate change conferences but that the plurality of actors ensures that some marginalized perspectives are heard that otherwise would risk being left out, perhaps showing that these two scenarios are not mutually exclusive. Further empirical work is, however, required to better understand the implications of the involvement of NGOs in global environmental governance on the legitimacy of evolving governance arrangements.

Another important issue that remains unresolved is the implications of the growing participation by NGOs in global environmental governance on environmental outcomes. The additional ideas, knowledge, and resources that NGOs bring to the table arguably contribute to enhancing 


\section{Naghmeh Nasiritousi}

environmental outcomes. On the other hand, the high degree of contestation within the NGO community (Betsill 2015; Nasiritousi et al. 2014; Duffy 2013) means that NGOs do not all pull in the same direction. While this may benefit global environmental governance in terms of adding to the plurality of voices, the high degree of contestation may also mean that different NGO efforts undermine each other, thereby reducing overall effectiveness. This is thus an issue where further empirical work is required. Given the considerable participation of NGOs in the contemporary global environmental governance landscape, the question concerning their effectiveness is not a yes or no issue. Instead of asking whether NGOs can contribute to effective global governance, it is necessary to examine how and under what conditions they can do so (Green 2013). As shown by Nasiritousi (2016), institutional arrangements that govern NGOs' participation in international affairs are important for setting the terms for which NGOs can participate effectively and with what effect.

As the world is facing increasingly pressing environmental challenges that the international system is ill-equipped to handle, the role of NGOs in global environmental governance is likely to grow. Hence, as NGOs play a more active role in global environmental governance, how these actors interact with other actors in the international system will be of continued interest to policy-makers and scholars. Future work should focus on analyzing the implications of the growing role of NGOs in this field and continue to map the conflicts and power structures within the heterogeneous NGO community. The patterns of cooperation and contestation that NGOs engage in ultimately add to the complexity of the international system. The way in which greater NGO engagement will impact on the political landscape in the long term is thus an important question for future studies.

\section{Notes}

1 https://sustainabledevelopment.un.org/mgos, accessed 16 January 2018.

2 www.climatenetwork.org/about/about-can, accessed 16 January 2018.

3 https://zerowasteeurope.eu/about.

4 This and subsequent sections draw on Nasiritousi (2016).

5 www.ipcc.ch/news_and_events/docs/factsheets/FS_what_ipcc.pdf, accessed 16 January 2018.

6 www.ipcc.ch/organization/organization_procedures.shtml, accessed 22 January 2018.

7 www.ipcc.ch/apps/contact/interface/organizationall.php, accessed 22 January 2018.

8 http://ccacoalition.org/en/partners, accessed 22 January 2018.

9 http://ndcpartnership.org/partners, accessed 22 January 2018.

$10 \mathrm{http}: / /$ priceofoil.org/2017/12/11/one-planet-sign-on-letter-stop-funding-fossils, accessed 29 January 2018.

11 www.worldbank.org/en/news/press-release/2017/12/12/world-bank-group-announcements-at-oneplanet-summit, accessed 29 January 2018.

12 https://gofossilfree.org/divestment/commitments, accessed 29 January 2018.

13 http://priceofoil.org/2017/09/07/the-lofoten-declaration-a-new-bar-for-climate-leadership, accessed 29 January 2018.

14 www.ft.com/content/027cb250-f9d2-11e7-9b32-d7d59aace167, accessed 29 January 2018.

15 http://sciencebasedtargets.org/about-the-science-based-targets-initiative, accessed 29 January 2018.

16 www.ghgprotocol.org/about-us, accessed 29 January 2018.

17 www.iclei.org/activities/agendas/low-carbon-city/gcc.html, accessed 29 January 2018.

18 http://climateaction.unfccc.int, accessed 30 January 2018.

\section{References}

Ayling J and Gunningham N. (2017) Non-state governance and climate policy: the fossil fuel divestment movement. Climate Policy 17: 131-149.

Bäckstrand K. (2006) Democratizing global environmental governance? Stakeholder democracy after the World Summit on Sustainable Development. European Journal of International Relations 12(4): 467-498.

Bäckstrand K and Kuyper JW. (2017) The democratic legitimacy of orchestration: the UNFCCC, nonstate actors, and transnational climate governance. Environmental Politics 26: 764-788. 
Bäckstrand K, Kuyper JW, Linnér B-O, et al. (2017) Non-state actors in global climate governance: from Copenhagen to Paris and beyond. Environmental Politics 26: 561-579.

Betsill M. (2015) NGOs. In: Bäckstrand K and Lövbrand E (eds) Research Handbook on Climate Governance. Cheltenham, UK: Edward Elgar Publishing, 251-261.

Betsill M and Corell E (eds). (2007) NGO Diplomacy: The Influence of Nongovernmental Organizations in International Environmental Negotiations. Cambridge, MA: MIT Press.

Betzold C. (2013) Business insiders and environmental outsiders? Advocacy strategies in international climate change negotiations. Interest Groups and Advocacy 2: 302-322.

Betzold C. (2014) Responsiveness or influence? Whom to lobby in international climate change negotiations. International Negotiation 19: 35-61.

Bowen A and Dietz S. (2016) The effects of climate change on financial stability, with particular reference to Sweden: a report for Finansinspektionen (The Swedish Financial Supervisory Authority), www. fi.se/contentassets/df3648b6cbf448ca822d3469eca4dea3/climat-change-financial-stability-sweden. pdf, accessed 22 January 2018.

Bulkeley H, Andonova LB, Betsill M, et al. (2014) Transnational Climate Change Governance. Cambridge: Cambridge University Press.

Burgiel SW and Wood P. (2012) Witness, architect, detractor: the evolving role of NGOs in international environmental negotiations. In: Chasek PS and Wagner LM (eds) The Road from Rio: Lessons Learned from Twenty Years of Multilateral Environmental Negotiations. Washington, DC: Resources for the Future Press, Routledge, 127-148.

Chan S, Falkner R, Goldberg M, et al. (2018) Effective and geographically balanced? An output-based assessment of non-state climate actions. Climate Policy 18: 24-35.

Chapin M. (2004) A challenge to conservationists. World Watch Magazine Nov/Dec: 17-31.

Dauvergne P and LeBaron G. (2014) Protest Inc.: The Corporatization of Activism. Cambridge: Polity Press.

Depledge J. (2005) Climate Change Negotiations. Toronto: Earthscan Canada.

Downie C. (2014) Transnational actors in environmental politics: strategies and influence in long negotiations. Environmental Politics 23: 376-394.

Duffy R. (2013) Global environmental governance and north-south dynamics: the case of the cites. Environment and Planning C: Government and Policy 31: 222-239.

Green JF. (2013) Rethinking Private Authority: Agents and Entrepreneurs in Global Environmental Governance. Princeton, NJ: Princeton University Press.

Hadden J. (2015) Networks in Contention: The Divisive Politics of Climate Change. Cambridge: Cambridge University Press.

Hanegraaff MC. (2015) Interest groups at transnational negotiation conferences: goals, strategies, interactions, and influence. Global Governance 21(4): 599-620.

Hjerpe M and Linnér B-O. (2010) Functions of COP side-events in climate-change governance. Climate Policy 10: 167-180.

Hjerpe M and Nasiritousi N. (2015) Views on alternative forums for effectively tackling climate change. Nature Climate Change 5: 864-867.

Hoffmann MJ. (2011) Climate Governance at the Crossroads: Experimenting with a Global Response after Kyoto. Oxford: Oxford University Press.

Finger M and Princen T. (1994) Environmental NGOs in World Politics: Linking the Local and the Global. Second edition. London: Routledge.

FSC-Watch. (2011) FSC "greenwashing" forest exploitation in Africa, www.fsc-watch.org/ archives/2011/06/17/FSC__Greenwashing__F, accessed 22 January 2018.

Gutner T. (2012) Evaluating World Bank environmental performance. In: Dauvergne P (ed.) Handbook of Global Environmental Politics. Cheltenham and Northampton, MA: Edward Elgar Publishing, 341-363.

Kanie N and Biermann F (eds). (2017) Governing Through Goals: Sustainable Development Goals as Governance Innovation. Cambridge, MA: MIT Press, 352.

Keck M, and Sikkink K. (1998) Activists Beyond Borders: Advocacy Networks in International Politics. Ithaca, NY: Cornell University Press.

Levin K, Cashore B, Bernstein S, et al. (2012) Overcoming the tragedy of super wicked problems: constraining our future selves to ameliorate global climate change. Policy Sciences 45: 123-152.

Linnér B-O, Hjerpe M and Nasiritousi N. (2013) Transnational agency in global environmental governance: images and self-images of roles played by non-state actors. ISA Annual Convention, San Francisco. 


\section{Naghmeh Nasiritousi}

Lövbrand E, Hjerpe M and Linnér B-O. (2017) Making climate governance global: how UN climate summitry comes to matter in a complex climate regime. Environmental Politics 26: 580-599.

MacDonald M. (2012) How Coca-Cola, McDonald's worked with nonprofits to get greener. GreenBiz, www.greenbiz.com/blog/2012/08/02/how-coca-cola-mcdonalds-worked-nonprofits, accessed 22 January 2018.

Mitchell RB. (2018) International Environmental Agreements Database Project (Version 2017.1). http://iea. uoregon.edu, accessed 22 January 2018.

Nasiritousi N. (2016) Shapers, Brokers and Doers: The Dynamic Roles of Non-State Actors in Global Climate Change Governance. Thesis (PhD). Linköping University.

Nasiritousi N. (2017) Fossil fuel emitters and climate change: unpacking the governance activities of large oil and gas companies. Environmental Politics 26: 621-647.

Nasiritousi N and Linnér B-O. (2016) Open or closed meetings? Explaining nonstate actor involvement in the international climate change negotiations. International Environmental Agreements: Politics, Law and Economics 16: 127-144.

Nasiritousi N, Hjerpe M and Buhr K. (2014) Pluralising climate change solutions? Views held and voiced by participants at the international climate change negotiations. Ecological Economics 105: 177-184.

Nasiritousi N, Hjerpe M and Bäckstrand K. (2016a) Normative arguments for non-state actor participation in international policymaking processes: functionalism, neocorporatism or democratic pluralism? European Journal of International Relations 22(4): 920-943.

Nasiritousi N, Hjerpe M and Linnér B-O. (2016b) The roles of non-state actors in climate change governance: understanding agency through governance profiles. International Environmental Agreements: Politics, Law and Economics 16: 109-126.

Nordang Uhre A. (2013) On Transnational Actor Participation in Global Environmental Governance. Thesis $(\mathrm{PhD})$, Stockholm Studies in Politics 152. Stockholm University.

O'Neill K. (2014) Architects, agitators, and entrepreneurs: international and nongovernmental organizations in global environmental politics. In: Axelrod R and VanDeveer SD (eds) The Global Environment: Institutions, Law, and Policy, 4th edition. Washington, DC: CQ Press, 26-52.

O'Neill K. (2017) The Environment and International Relations. Second edition. Cambridge: Cambridge University Press.

Ramstein C. (2012) Rio+20 Voluntary Commitments: delivering promises on sustainable development?, Working Paper No. 23/12, IDDRI, Paris, France.

Raustiala K. (1997) States, NGOs, and international environmental institutions. International Studies Quarterly 41(4): 719-740.

Rietig K. (2016) The power of strategy: environmental NGO influence in international climate negotiations. Global Governance 22: 269-288.

Schroeder H and Lovell H. (2011) The role of non-nation-state actors and side events in the international climate negotiations. Climate Policy 12: 23-37.

UN. (2015) Transforming our world: the 2030 Agenda for Sustainable Development, A/RES/70/1. Resolution adopted by the General Assembly on 25 September 2015, www.un.org/ga/search/view_ doc.asp?symbol=A/RES/70/1\&Lang=E, accessed 16 January 2018.

UNFCCC. (2017) In-session workshop on opportunities to further enhance the effective engagement of non-Party stakeholders with a view to strengthening the implementation of the provisions of decision 1/CP.21. Report by the Secretariat. FCCC/SBI/2017/INF.7.

Vidal J. (2012) Rio+20: reasons to be cheerful, The Guardian, 27 June, www.theguardian.com/globaldevelopment/poverty-matters/2012/jun/27/rio20-reasons-cheerful, accessed 16 January 2018.

Wapner P. (1995) Politics beyond the state environmental activism and world civic politics. World Politics 47(3): 311-340.

Watts J. (2012) Rio+20 protesters perform "ritual rip-up" of negotiated text, The Guardian, 21 June, www. theguardian.com/environment/2012/jun/21/rio-20-protesters-text-agreement, accessed 16 January 2018.

Willetts P. (1996) From Stockholm to Rio and beyond: the impact of the environmental movement on the United Nations consultative arrangements for NGOs. Review of International Studies 22(1): 57-80. 